\title{
The Decline of Mandatory Physical Education in Grade Schools Resulated in THE CURRENT CHILDHOOD OBESITY CRISIS AND CONSEQUENTLY AN UNSUSTAINABLE RISE IN HEALTh CARE SPENDING
}

Frandy St. Louis ${ }^{*}$

I. INTRODUCTION

A. The Issue

II. The SuCCESS OF Federally MANDATEd PHYSICAL

EDUCATION FOLLOWING WORLD WAR I

III. DECLine of MANDatory Physical Education IN PUbliC

SCHOOLS AND THE SUBSEQUENT RISE IN CHILDHOOD

OBESITY THROUGH A CHANGING LANDSCAPE..................636

IV. PROLIFERATION OF JUNK FOODS .......................................639

V. THE REAL COST OF OBESITY AS REFLECTED IN INCREASED

HEAlTH CARE SPENDING 640

A. The Scope of the Problem and Its Undeniable

Gravity

VI. The CuRRENT Status of STATE LAWS AND TheIR

DOCUMENTED FAILURES SUPPORT A FEDERAL

MANDATE

VII. A FEDERAL MANDATE WILL WITHSTAND A

CONSTITUTIONAL CHALLENGE.

VIII. SOLUTIONS TO THE PROBLEMS OF CHILDHOOD

OBESITY.

A. Principal 658

B. Alternative Solution 660

IX, CONCLUSION. 661

\section{INTRODUCTION}

The empirically-minded, father of the field of logic, and pioneer of Greek philosophy, Aristotle (writing in politics-

J.D., Indiana University Robert H. McKinney School of Law, 2013; B.A., Georgia State University, 2010. 
$350 \mathrm{BCE}$ ), recognized more than two thousand years ago that "Education" (including physical education) is a function of the State. ${ }^{1}$ He further elaborated that education should be guided by legislation to make it correspond with the results of psychological analysis, and follow the gradual development of the physical and mental faculties of the individual. ${ }^{2}$ For Aristotle education-both traditional and physical-was a proper matter to be legislated. Given the pre-eminence of Greek philosophy and politics in the development of our modern society and political democracy, the theoretical construct of legislating physical education through a federal mandate can be said to have its roots in established political principles. ${ }^{3}$ This note will argue for a federal mandate requiring public schools to offer-as part of their curriculum-specific standards of physical education at all grade levels as a solution to the childhood obesity crisis and to reverse the long-running upward trend in healthcare related expenditures.

But why is this question of physical education even relevant to the issue of childhood obesity and health care expenditures? After years of manifest neglect, the crisis of childhood obesity and the debate surrounding it have moved to the forefront of the nation's consciousness. ${ }^{4}$ While this

1 Charles Hummel, Aristotle (384-322 B.C.), 23 Prospects 39 (1993), available at http://www.ibe.unesco.org/publications/ThinkersPdf/ aristote.pdf ("No one can doubt that it is the legislator's very special duty to regulate the education of youth ... [w] conclude, therefore, that education must be regulated by law, and that it must be controlled by the state.").

2 Id.

3 Wordology, Rise of Western Culture \& Philosophy (Classical Greece), http://www.worldology.com/Europe/Europe_Articles/rise_of_ western_culture.htm (last visited Jan. 15, 2013) (declaring that "western thought and culture traces its roots to Classical Greece philosophy, which is based upon reason and inquiry pertaining to a variety of disciplines, including science, technology, literature, law, politics, economics, psychology, ethics, art, etc").

4 Don Lemon, The Debate over Childhood Obesity, CNN (Feb.15, 2010, 11:20 AM), http://newsroom.blogs.cnn.com/2010/02/15/the-debateover-childhood-obesity/ ("First lady Michelle Obama states that 1-in"3 American children is overweight; 1 -in-2 among minorities. Now she has launched Let's Move, a national program to get rid of junk food in public schools and educate children about proper diet and exercise. President 
crisis has become severe and pervasive, its cause is arguably well understood and there are steps that can and must be taken to confront it. 5

\section{A. The Issue}

Over the past few years, the majority of citizens and politicians alike have come to recognize that the nation is facing a childhood obesity crisis that is having an alarming impact on overall health and, as a consequence, an unsustainable rise in health care related expenditures. ${ }^{6} \mathrm{~A}$ recent study by the Fortanasce-Barton Neurology Center shows that children today are four to five times more likely to be obese (and as much as eight times more likely to be overweight) than in the $1960 \mathrm{~s}$ and $70 \mathrm{~s} .{ }^{7}$ As a result of the rise in childhood obesity, the prevalence of preventable diseases (such as Type II diabetes, high blood pressure, certain heart conditions, and even premature death) among

Obama backed her up by establishing a federal task force to tackle the issue and come up with a plan of action in ninety days.").

5 Thomas R. Frieden et al., Reducing Childhood Obesity Through Policy Change: Acting Now To Prevent Obesity, 29 HEALTH AFF. 357 (2010), available at http://www.banpac.org/pdfs/sfs/2010/reduc_child_ obes_11_04_10.pdf ("Childhood obesity is an epidemic in the United States, and is expected to increase the rates of many chronic diseases. Increasing physical activity and improving nutrition are keys to obesity prevention and control. But changing individual behavior is difficult. A comprehensive, coordinated strategy is needed. Policy interventions that make healthy dietary and activity choices easier are likely to achieve the greatest benefits. There is emerging evidence on how to address childhood obesity, but we must take action now to begin to reverse the epidemic.").

6 A. Must et al., Long-Term Morbidity and Mortality of Overweight Adolescents (A Follow-Up of The Harvard Growth Study of 1922 to 1935), 327 NEW ENG. J. MED. 1350 (1992), available at http://www.ncbi.nlm.nih.gov/pubmed/1406836; Preventing Chronic Diseases: Investing Wisely in Health, CDC, http://www.cdc.gov/ nccdphp/publications/factsheets/prevention/pdf/obesity.pdf (hereinafter Preventing Chronic Diseases).

7 Fortanasce-Barton Neurology Center, A New Year for a Vital Child, http://fortanasceclinic.com/a-new-year-for-a-vital-new“child.html (last visited Jan. 15, 2013). 
children has become all too common. ${ }^{8}$ Given the magnitude of this crisis, it is important to explore its genesis in an attempt to first understand its anatomy, and ultimately adopt a plan that would provide a solution without undue delay. ${ }^{9}$

In exploring the childhood obesity crisis, it is important to understand that while its effects have already taken a tremendous toll on the nation, its making has been rather incremental and gradual. ${ }^{10}$ It is the unintended consequences of decisions that could plainly be said to have been shortsighted and improvident. ${ }^{11}$ As a result of these decisions, the United States is now at a point in history where it faces an exigency that-if not swiftly, fully and comprehensibly dealt with-will continue to cause tremendous damages to the nation's social infrastructures. To address this crisis, it is critical that there be a national

8 A. Must, supra note 6; Preventing Chronic Diseases, supra note 6 .

9 See Victoria L. BRESCOLL ET AL., THE ANNALS OF THE AMERICAN ACADEMY OF POLITICAL AND SOCIAL SCIENCE 178-79 (2008), a vailable at http://ann.sagepub.com/content/615/1/178.full.pdf + html (emphasizing that "more than $17 \%$ of American children and adolescents are overweight or obese, with certain subgroups, such as African American youth, having even higher prevalence rates ( $18 \%$ to $26 \%$ ), leading to increased incidences of hypertension, diabetes, and even heart attacks among obese children").

10 JefFrey P. KoPlan ET AL., PREventing ChILdhood Obesity: HEALTH IN THE BALANCE, available at http://www.banpac.org/pdfs/sfs/ 2010/reduc_child_obes_11_04_10.pdf (discussing the toll already paid for the obesity crisis).

11 Ted Vilaire, Decline of Physical Activity, http://prorev.com/ bigpage.htm (last visited Jan. 30, 2013) (Vilaire notes that "once customary for children at nearly every grade level, gym class has been steadily scaled back in recent years. Just during the past decade, the number of U.S. high school students attending daily physical education classes dropped from $42 \%$ to $29 \%$. According to the National Association for Sport and Physical Education (NASPE), the nation's largest organization for physical education teachers, currently, nearly half of all students and $75 \%$ of high school students do not attend any physical education classes. Judith Young, executive director of NASPE, maintains that schools cut gym classes for lack of funding, but more often cuts result from time constraints that develop with the addition of new curriculum. Standards-based reform has been detrimental to physical education."). 
federal mandate requiring all public schools to incorporate specific minimum standards of physical education in their curriculum at all grade levels.

To further elaborate on the imperative and need of a federal mandate requiring public schools to incorporate minimum standards of physical education in their curriculum, this note emphasizes solutions proposed by the American Heart Association Task Force on Physical Activity, and expands upon them for a more thorough approach. In order to facilitate a better understanding of the problem, and lay the groundwork for resolving it, section II sets forth the general background of physical education through a historical perspective, and focuses on its effects on the nation's childhood obesity rate. Section III follows the decline of mandatory physical education and underlines the subsequent rise in the childhood obesity rate. Section IV covers the proliferation of the junk food industry and its role in contributing to the problem. Section V explains the rise in health care expenditures in relation to the rise in the childhood obesity rate. Following this discussion, section VI introduces different state laws and analyzes their effects on the childhood obesity rate. Section VII addresses potential constitutional challenges to a federal mandate designed to tackle the problem. And lastly, section VIII proposes comprehensive solutions that should be adopted as part of a federal program mandating physical education at all grade levels for students attending public schools.

\section{The SucCess of Federally MANDAted Physical EDUCATION FOLLOWING WORLD WAR I}

According to Lance C. Dalleck and Len Kravitz, "in the United States, the early educational process [principally] focused on intellectual matters."12 "Schools concentrated on teaching traditional subjects including reading, writing,

12 Lance C. Dalleck \& Len Kravitz, History of Physical Education, http://www.unm.edu/ lkravitz/Article\%20folder/history.html (last visited Mar. 9, 2013). 
arithmetic, and religious matters."13 "Physical education remained missing from the public education system for the better part of the nineteenth century" until Dr. J.C. Warren-a medical professor at Harvard University and strong proponent of physical activity-developed credible evidence that showed the proper functioning of the body and mind necessitated regular exercise. ${ }^{14}$

Dalleck and Kravitz noted that "[o]ne of the most important events [in the history of physical education] in the United States was the Industrial Revolution." Advancement in industrial and mechanical technologies changed the way people lived and worked. ${ }^{15}$ The cost of industrialization became conspicuously apparent in the mid-20th century as people started to develop-never before prevalent-diseases including, but not limited to, hypokinetic diseases, cardiovascular disease, cancer, and Type II diabetes. ${ }^{16}$

After World War I was fought and won, the federal government released statistics from the draft that revealed that one out of every three draftees "was unfit for combat and many of those drafted were highly unfit prior to military training." 17 To address the problem, "the government and many of the states passed legislation that ordered the improvement of physical education programs in

13 Id. (explaining that "in the United States, the early educational process focused primarily on intellectual matters and was not concerned with physical education").

14 Id.

15 Id. (" $[\mathrm{A}]$ dvancement in industrial and mechanical technologies replaced labor-intensive jobs. Rural life changed to an urban lifestyle. The new city life generally required less movement and work compared to rural life, consequently decreasing levels of physical activity.").

16 Id. (" $[\mathrm{A}] \mathrm{n}$ epidemic of hypokinetic diseases including cardiovascular disease, cancer, and Type II diabetes, never before prevalent, began to be recognized as the leading causes of disease and death. The lifestyle improvements brought in part by the Industrial Revolution had apparently come with an unwanted and alarming cost to health.").

17 Id. 
public schools that resulted in improved health for the overall population."18

However, "[t]he gains that physical education programs made through the passage of legislation following World War I were short-lived" as the nation's attention shifted to the reality of the Great Depression and subsequent developments in Europe. ${ }^{19}$ The United States unwillingly was drawn into "World War II with the bombing of Pearl Harbor on December 7, 1941."20 "With the War came the need to once again draft military personnel". ${ }^{21}$ And again, during the draft, it became clear that many of the draftees were not physically fit for battle. ${ }^{22}$ "When the War was over, it was reported that nearly half of all draftees [were] rejected or were given non-combat positions due to being overweight." 23

These alarming statistics once more attracted the attention of the country "with regards to the importance of [physical education]," and the government would once again try to re-introduce more stringent and pronounced physical education programs in the nation's public school system. ${ }^{24}$ At the heart of this renewed focus on physical education was the Presidential Council on Youth Fitness whose role was to advise the President-through the Secretary of Health and Human Services-about physical activity, fitness, and sports, and put forth programs to promote

18 Id. (The article notes that national Park Service legislation designed to promote both physical and traditional education was passed in 1920. Among them were: the American Physical Education Association, the American Association for Health and Physical Education, the Playground and Recreation Association, National Code of Standards for Physical Education and more.).

19 Id. (explaining that "funding for these programs became limited and eventually was exhausted as emphasis in the poor economy was forced to shift elsewhere").

$\begin{array}{ll}20 & I d . \\ 21 & I d . \\ 22 & I d . \\ 23 & I d . \\ 24 & I d .\end{array}$ 
regular physical activity for the health of all Americans. ${ }^{25}$ Since the establishment of the Council, many changes in technologies, priorities and politics have continued to affect the development of physical education in the nation's public school system. These changes and their consequences are explored below.

\section{Decline of Mandatory Physical Education IN Public SCHOOLS AND THE SUBSEQUENT RISE IN CHILDHOOD OBESITY THROUGH A CHANGING LANDSCAPE}

The atmosphere that created the renewed focus on physical education after World War II once again did not endure. Greater and accelerated technological advances, the need to expand public schools curriculum, and budget crisis that began in the 1970s (and lasted through the 80s) brought to the forefront different priorities that would eventually bring an ensuing and protracted decline in mandatory physical education. ${ }^{26}$ As mandatory physical education continued to decline and technology continued to facilitate a more sedentary lifestyle, the rise in childhood obesity gradually and progressively took hold. ${ }^{27}$ The

25 Our History, PCFSN, http://www.fitness.gov/about-pcfsn/ourhistory/ (last visited Jan. 30, 2012) (presenting the history of the Presidential Council on Youth Fitness).

26 Emma Murray, History of Physical Education in Schools, EHow.COM, http://www.ehow.com/about_6521673_history-physicaleducation-schools.html\#ixzz1YuwWeCtZ (last visited Jan. 30, 2012) ("[I]n 1955, the President's Council on Physical Fitness and Sports was created to promote fitness among youth through PE programs in schools and other organizations, such as the YMCA. In 1976, it reported that fewer than 40 percent of students in the public schools took part in daily $\mathrm{PE}$ activities. The daily requirements for $\mathrm{PE}$ in high schools that were stipulated by many states declined as a result of the addition of other elective subjects. Moreover, recessions during the 1970s and 1980s resulted in cuts to several education programs in schools, including physical education.").

27 Cynthia L. Ogden et al., The Epidemiology of Obesity, 132 GASTROENTEROLOGY 2087 (2007), available at http://www.gastrojournal. org/article/S0016-5085(07)00579-3/abstract (last visited Mar. 19, 2013); see also Prevalence of Sedentary Lifestyle - Behavioral Risk Factor Surveillance System, United States, 1991, CDC, http://www.cdc.gov/ mmwr/preview/mmwrhtml/ 00021313.htm (last visited Jan. 30, 2013) 
following graph, compiled from data collected by the CDC, demonstrates the impact of declining levels of physical education on the prevalence of childhood obesity in the last quarter of the $20^{\text {th }}$ century ${ }^{28}$ :

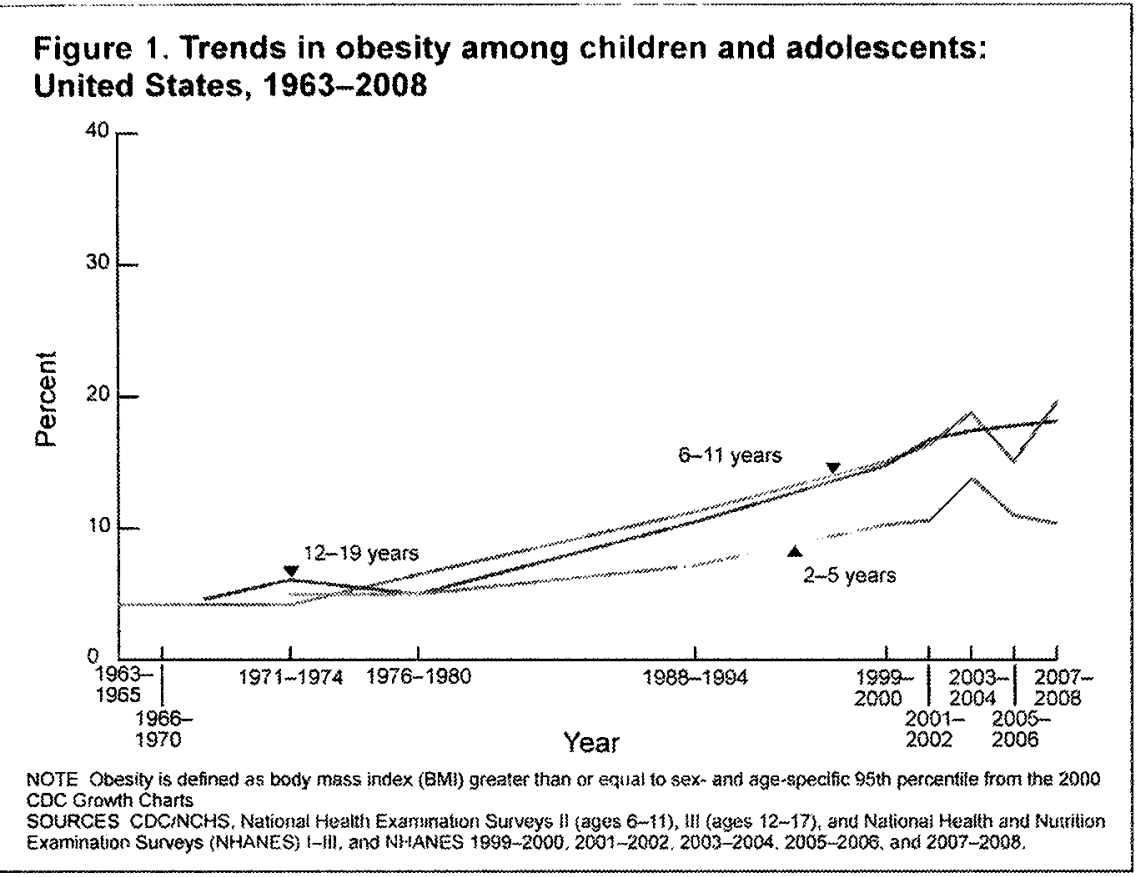

As the graph shows, when physical education was in the national consciousness (in the years following World War II and prior to the financial crisis of the 1970s), childhood obesity had for the most part stabilized. ${ }^{29}$ In fact, among twelve to nineteen year-olds, the already substantially low

(defining sedentary lifestyle as "a medical term used to denote a type of lifestyle with no or irregular physical activity, and commonly characterized by sitting, reading, watching television and computer use for much of the day with little or no vigorous physical exercise").

28 CDC Grand Rounds: Childhood Obesity in the United States, CDC (Jan. 21, 2011), http://www.cdc.gov/mmwr/preview/mmwrhtml/ mm6002a2.htm (last visited Mar. 19, 2013) (The article describes "the prevalence of obesity among children and adolescents, by age group, in the United States during 1963-2008. In the United States, childhood obesity affects approximately 12.5 million children and teens $-17 \%$ of that population. Changes in obesity prevalence from the 1960 s show a rapid increase in the 1980 s and $1990 \mathrm{~s}$, when obesity prevalence among children and teens tripled from nearly $5 \%$ to approximately $15 \%$.").

$29 \quad I d$. 
level of childhood obesity actually saw a decline from 1972 to $1978 .{ }^{30}$

However, as national requirements started to give way to a more local/state base deferential system, the positive trend ended, and since, the childhood obesity rate has steadily and doggedly increased. ${ }^{31}$ Hence, the correlative rise in childhood obesity is shown on the graph. ${ }^{32}$ This correlation, though debatable, cannot merely be discounted. Such a sharp rise after what is manifestly a notable period of stability deserves profound scrutiny as the totality of this crisis within the framework of its effect on the nation's overall health and its associated costs is examined.

In keeping with the concept of totality, it is necessary to ask whether there are other factors that might have contributed to, or might be responsible for the childhood obesity crisis. Though the answer to this question may require a more comprehensive study, it should be noted that that during the 1970s televisions became a staple in American households, and that such a development could have contributed to the increase in the childhood obesity rate as both parents and children took to watching TV as opposed to taking a stroll at the neighborhood park. ${ }^{33}$ While this historical development is important, its consequences were rather minimal-thereby making its contribution to the childhood obesity crisis negligible. ${ }^{34}$ Such a finding

$\begin{array}{ll}30 & \text { Id. at } 43 . \\ 31 & I d . \text { at } 44 . \\ 32 & \text { Id. at } 46 . \\ 33 & \text { LYNN SPIGEL, MAKE ROOM FOR TV: TELEVISION AND THE FAMILY }\end{array}$ IDEAL IN POSTWAR AMERICA 57 (1992).

34. William H. Dietz, Jr. \& Steven L. Gortmaker, Do We Fatten Our Children at the Television Set? Obesity and Television Viewing in Children and Adolescents, 75 AM. ACAD. PEDIATRICS 807 (1985), available at http://www.ncbi.nlm.nih.gov/pubmed/3873060 (last visited Mar. 19, 2013) ("[T]he association of television viewing and obesity in data collected during cycles II and III of the National Health Examination Survey were examined. Cycle II examined 6,965 children aged 6 to 11 years and cycle III examined 6,671 children aged 12 to 17 years. Included in the cycle III sample were 2,153 subjects previously studied during cycle II. These surveys, therefore, provided two crosssectional samples and one prospective sample. In all three samples, significant associations of the time spent watching television and the 
further highlights the effects of the decline of mandatory physical education and the subsequent epidemical rise in childhood obesity that followed. Reintroducing mandatory physical education standards at all grade levels in the public school system is the right and proper step to resolving this devastating crisis.

\section{PROLIFERATION OF JUNK FOODS}

It is significant to recognize that the decline of mandatory physical education coincided with an unprecedented proliferation of the junk food industry. ${ }^{35}$ The 1960 s, 70 s and 80 s saw the industry reach a critical level of pervasiveness, and the trend continues today. ${ }^{36}$ It should also be noted that there have been some proposals, and (in some cases) actual regulations targeting the junk food industry. ${ }^{37}$ The effects of these proposals/regulations,

prevalence of obesity were observed. In 12- to 17-year-old adolescents, the prevalence of obesity increased by $2 \%$ for each additional hour of television viewed. The associations persisted when controlled for prior obesity, region, season, population density, race, socioeconomic class, and a variety of other family variables. The consistency, temporal sequence, strength, and specificity of the associations suggest that television viewing may cause obesity in at least some children and adolescents. The potential effects of obesity on activity and the consumption of calorically dense foods are consistent with this hypothesis."); see also A Growing Problem, CDC, http://www.cdc.gov/ obesity/childhood/problem.html (last visited Jan. 30, 2013) ("[C]hildren 8-18 years of age spend an average of 7.5 hours a day using entertainment media, including TV, computers, video games, cell phones, and movies. Of those 7.5 hours, about 4.5 hours is dedicated to viewing TV. Eighty-three percent of children from 6 months to less than 6 years of age view TV or videos about 1 hour and 57 minutes a day. TV viewing is a contributing factor to childhood obesity because it may take away from the time children spend in physical activities.").

35 ERIC SCHLOSSER, FAst FOOD NATION: THE DARK Side OF THE ALL-AMERICAN MEAL 3-8 (2007) (noting that "while the junk food industry was created in the early $20^{\text {th }}$ century, it had not grown before like it did during the period in question").

36 Id. at 4.

37 Rudd Center Releases Unprecedented Report on Fast Food Nutrition and Marketing to Youth, YALE RUDD CENTER (Nov. 2010), http://www.yaleruddcenter.org/newsletter/issue.aspx?id=27 (last visited 
however, have proven so far to be inconclusive. ${ }^{38}$ Based on currently available evidence, while junk foods can be said to be a contributing factor to the childhood obesity crisis, physical education arguably has been and remains the greater factor. ${ }^{39}$ And historically, given that physical education was once embraced nationally as a way to curb the country's obesity problem, it is likely to be politically more palatable-making it easier to be federally legislated.

\section{THE REAL COST OF OBESITY AS REFLECTED IN INCREASED Health CaRe SPENDING}

The high and growing cost of health care is a critical issue for businesses, workers, government and citizens alike.40 Spending on health care for 2009 accounted for $17.6 \%$ of GDP which amounted to a record of $\$ 2.5$ trillion. ${ }^{41}$

Mar. 19, 2013) ("A struggle is occurring in San Francisco about a proposed requirement for fast food meals to meet nutrient standards in order to include toys. Sponsored by Supervisor Eric Mar and approved by the Board of Supervisors, the proposal was vetoed by Mayor Gavin Newsom. The Board's eight of 11 votes in support of the proposal will allow it to override Mayor Newsom's veto.").

38 EILEEN SALINSKY, EFFECTS OF FoOd MARKETING To KidS: I'M LOVIN' IT? (2006), available at http://www.nhpf.org/library/issuebriefs/IB814_FoodMarketing_08-15-06.pdf.

$39 \quad I d$.

40 Neeraj Sood et al., The Effect of Health Care Cost GROWTH ON THE U.S. ECONOMY (2007), available at http://aspe.hhs.gov/health/reports/08/healthcarecost/report.html (last visited Mar. 19, 2013) ("Rising health care costs have generated concerns that continued growth could adversely affect the nation's economy, as well as pose problems for particular sectors of the economy, such as employers and households. This report evaluated how increased spending on health care affected aggregate economic indicators and individual sectors. As a basis for this investigation, a thorough and detailed review of the literature was conducted that included anecdotal evidence, survey findings and the peer reviewed literature. The literature review highlighted the economic effects of health care cost growth, and identified possible mechanisms through which cost growth could affect the aggregate economy, as well as government, households and business.").

41 National Health Expenditure Data, CMS (Apr. 11, 2012), https://www.cms.gov/nationalhealthexpenddata/02_nationalhealthaccou ntshistorical.asp (last visited Mar. 19, 2013). 
In 1970 , the U.S spent about $\$ 75$ billion on health care, or $\$ 356$ per resident-which accounted for only $7.2 \%$ of GDP. ${ }^{42}$ As if the staggering increase over the past four decades is not alarming enough, the Henry J. Kaiser Family Foundation projects that by 2016 health care spending will be over $\$ 4.1$ trillion, or $\$ 12,782$ per resident, and account for $19.6 \%$ of GDP. ${ }^{43}$ This is what the United States faces if it fails to act to put a stop to run-away health care costs. Promisingly, multiple studies have shown that addressing childhood obesity could significantly and meaningfully reduce these run-away costs and pre-empt further worsening of this crisis. ${ }^{44}$ Based on the historical background, a federal mandate requiring minimum standards of physical education at all grade levels in the nation's public school system is an effective way to address the childhood obesity crisis while at the same time reversing the ever rising trend of health care expenditures.

\section{A. The Scope of the Problem and Its Undeniable Gravity}

Over the past four decades, the number of overweight children and adolescents has risen, and these increases cut across all racial and ethnic groups, and both genders. ${ }^{45}$ Studies have shown that overweight and obese children are at substantial risk of illness from high blood pressure, high

42 Id.

43 Kaiser family foundation, TRends in Health Care Costs AND SPENDING (2007), available at http://www.kff.org/insurance/upload/ 7692.pdf.

44 Youfa Wang et al., Will All Americans Become Overweight or Obese? Estimating the Progression and Cost of the US Obesity Epidemic, 16 OBESITY 2323 (2008), available at http://www. readcube.com/articles/10.1038/oby.2008.351 (last visited Mar. 19, 2013) (predicting that "the prevalence of overweight children will nearly double by 2030 and that total health care costs attributable to obesity will double every decade to $\$ 860.7-956.9$ billion by $2030 ")$.

45 Obesity: Halting the Epidemic by Making Health Easier, CDC (May 26, 2011), http://www.cdc.gov/chronicdisease/resources/publications/ aag/obesity.htm (last visited Mar. 19, 2013). 
cholesterol, Type II diabetes, heart disease and stroke. ${ }^{46}$ Because of the likelihood of diseases among obese children who most often grow up to be obese adults, there are enormous economic costs that are associated with this epidemic. ${ }^{47} \mathrm{~A}$ recent study examining the impact of obesity on rising medical spending found that the increase in obesity contributed to inordinate spending increases for the three medical conditions examined (diabetes, hyperlipidemia, and heart disease).48 Between 1987 and 2001, growth in obesity and spending on obese people accounted for $27 \%$ of the growth in inflation-adjusted per capita health care spending. 49

Furthermore, former United States Surgeon General Richard Carmona recently stated that childhood obesity impacts not only children's personal health, but also society as a whole. ${ }^{50}$ It has been proven that the problem of childhood obesity goes beyond excess weight and disabling diseases to include negative impact on mental health and

46 Id. ("Obesity increases the risk of many health conditions, including the following: coronary heart disease, stroke, and high blood pressure, Type II diabetes, cancers, such as endometrial, breast, and colon cancer, high total cholesterol or high levels of triglycerides, liver and gallbladder disease, sleep apnea and respiratory problems, degeneration of cartilage and underlying bone within a joint (osteoarthritis), reproductive health complications such as infertility, and mental health conditions.").

47 Id. ("In 2008, overall medical care costs related to obesity for U.S. adults were estimated to be as high as $\$ 147$ billion. People who were obese had medical costs that were $\$ 1,429$ higher than the cost for people of normal body weight. Obesity also has been linked with reduced worker productivity and chronic absence from work.").

48 Kenneth E. Thorpe et al., Trends: The Impact of Obesity on Rising Medical Spending, HeALTHAFFAIRS (Oct. 20, 2004), http:// content.healthaffairs.org/content/suppl/2004/10/15/hlthaff.w4.480.DC1 (last visited Mar. 21, 2013).

49 Id.

50 The Growing Epidemic of Childhood Obesity: Testimony Before the Subcommittee on Competition, Infrastructure, and Foreign Commerce, Committee on Commerce, Science, and Transportation, 109th Cong. (2004) (statement of Richard H. Carmona, Surgeon General), available at http://www.surgeongeneral.gov/news/testimony/ childobesity03022004.html (last visited Mar. 21, 2013). 
school performance. ${ }^{51}$ There is growing evidence documenting the association between obesity and poor mental health. ${ }^{52}$ Researchers in the Adult and Community Health Division of the CDC analyzed 2006 "data and found that depression and anxiety are associated with obesity." 53 As a result, they advised that "public health intervention [] address mental and physical health as a combined entity, and that programs to simultaneously improve mental health and physical health should be developed and implemented." 54 Given the primacy of children to the nation's future, childhood obesity should be considered-as indicated by former Surgeon General of the United States, Dr. Richard Carmona-a "dire" threat to our society. ${ }^{55}$ Considering the role of physical education in the history of obesity following World War I and II, a federal program mandating minimum standards of physical education in the public school system is a demonstrated and established way to address this "dire" threat.

\section{The CurRent Status of State LaWs and Their DOCUMENTED FAILURES SUPPORT A FEDERAL MANDATE}

According to the CDC, "federal law does not prescribe minimum standards for physical education in schools." 56 The federal government instead "relies on grant programs administered by the Departments of Education and Transportation to create incentives that promote [not

51 Mental Health, Stress and Obesity, TRUST FOR AMERICA'S HEALTH, http://healthyamericans.org/pages/?id=253 (last visited Jan. $30,2013)$.

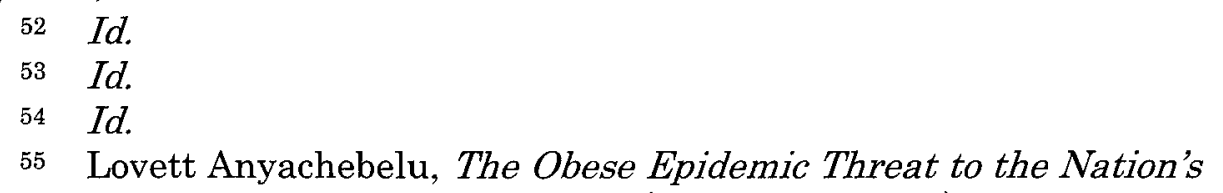
Security, FORT GORDON SIGNAL (April 1, 2011), http://www. fortgordonsignal.com/news/2011-04-01/News_Update/The_obese_epidemic threat_to_the_Nations_security.html (last visited Mar. 21, 2013).

56 Physical Activity for School Age Children, CDC (Apr. 13, 2012), http://www.cdc.gov/phlp/winnable/school_activity.html (last visited Mar. $21,2013)$. 
mandate)] physical activities in the school setting." 57 Without a federal mandate, "state and local jurisdictions have passed a variety of laws and policy "recommendations" that define minimum standards for time requirements and the quality of physical education and recess." 58

Below are examples of physical education laws and policy considerations for the state of Oregon, Arkansas, and Tennessee. The Oregon physical education requirements statute reads as follows:

Every public school student in kindergarten through grade [eight (8)] shall participate in physical education for the entire school year. Students in kindergarten through grade [five (5)] shall participate in physical education for at least 150 minutes during each school week. Students in grades [six (6)] through [eight (8)] shall participate in physical education for at least 225 minutes during each school week. ${ }^{59}$

According to the National Association of State Boards of Education in Arkansas:

Act 317 (2007) requires [sixty 60] minutes per calendar week of physical education training and instruction for students in grades [five (5) through eight (8)] for schools organized to teach these grades. The statute requires [ninety (90)] minutes of additional physical activity per week for grades $\mathrm{K}-6$, which may include physical education in addition to the previous requirement, daily recess, or intramural sports. Code 20-7-135 (2003) calls on the State Board of Education to promulgate

$57 \quad I d$.

58 Id. ("State and local quantitative policies vary ranging from no time requirement to an established minimum number of minutes students must participate in physical activity each week. Qualitative standards also vary among jurisdictions ....").

59 Oregon Educational Act for the 21st Century, OR. REV. STAT. $§$ 329.496(1) (2012). 
rules and regulations to ensure physical activity standards are implemented to provide students with the skills, opportunity, and encouragement to adopt healthy lifestyles. The Rules Governing Nutrition and Physical Activity Standards and Body Mass Index for Age Assessment Protocols in Arkansas Public Schools include the time requirements of Act 317 (2007), and allow local districts to require physical education or activity in excess of these requirements. ${ }^{60}$

In Tennessee, a policy task force, in response to its position on the importance of physical education, has published the following recommendations:

Children need opportunities to be physically active and have access to healthful foods in order to grow, learn, and thrive. Physical activity needs to be balanced with good nutrition in order to create a healthy learning environment. Physical activity has substantial health benefits for students including favorable effects on body weight, blood pressure, endurance capacity and physical strength to promote healthy lifelong learning. Physical activity has been shown to promote good academic outcomes and to reduce barriers to learning. Good health fosters student attendance in education and helps to increase a student's capacity for learning. Community participation is essential to the development and implementation of school policies that

60 State School Healthy Policy Database, NAT'L AsS'N OF STATE BDS. OF EDUC., http://nasbe.org/healthy_schools/hs/bytopics.php?topicid $=1110 \&$ catExpand=acdnbtm_catA (last visited Jan. 26, 2013). 
support and promote physical activity and good nutrition in the school setting. ${ }^{61}$

These types of laws and policy positions have been considered to varying degrees and, on occasions, adopted in several states. ${ }^{62}$ However, without federal minimum standards, local communities are often left to decide whether to include any physical education at all in their curriculum. ${ }^{63}$

In the face of budget restraints, and the fungibility of money (not to mention differing political approaches based on ideology), physical education expense is often the first school expense to be eliminated. ${ }^{64}$ Despite a pronounced recognition of the importance of physical education in the school setting - as evidence by the many debates, policy consideration and attempts to pass legislation in this areamany of the measures that have so far emerged have contributed to more of a conceptual framework of physical education rather than explicit requirements (which are essential to implementing a successful physical education program in the public school system). ${ }^{65}$

To illustrate this point, in California, although physical education is required, a 2006 audit of the state's "public

61 Physical Activity Policy, Tenn. State Bd. OF Educ. (Apr. 15, 2005), http://www.tn.gov/education/schoolhealth/physed/doc/IIIC_Physical_ Activity_Policy.pdf.

62 State Legislative and Regulatory Action to Prevent Obesity and Improve Nutrition and Physical Activity, CDC, http://www.cdc.gov/nocdphp/ dnpao/docs/chronic-disease-state-policy-tracking-system-methodology-report-508.pdf.

$63 I d$.

64 Betsy Hurd, Physical Education too Valuable to Sacrifice to Budget Cuts, MLIVE (Feb. 6, 2010, 5:03 AM), http://www.mlive.com/ opinion/saginaw/index.ssf/2010/02/physical_education_too_valuabl.html (last visited Mar. 21, 2013).

65 Melinda Bossenmeyer, Case Study Could Shape Physical Education Landscape Across Nation, PeAceful PlaYgournds, $\mathrm{http}: / /$ www.peacefulplaygrounds.com/physical-education-case-study.htm (last visited Jan. 30, 2013) ("[Physical education] is required, but it is not taught. According to the latest School Health Policies and Program Study report (2006) [i] only $13.7 \%$ of elementary schools, $15.2 \%$ of middle schools and astonishingly, only $3 \%$ of high schools provided physical education at least 3 days per week or its equivalent for the entire school year for students in all grades in the school."). 
elementary schools found that less than $36 \%$ of the students were receiving elementary school physical education."66 This phenomenon is not unique to California. The New York Department of Education recently released results of an audit that "found limited evidence that any of the sampled schools were in compliance with the physical education requirements." 67 This current state of affairs is unacceptable given that a great number of studies over the past decade have shown that physical activity is extremely important and positively correlated to a child's proper development (both mental and physical). 68

Against the background of current state laws that deals with physical education in the public school system, it is necessary to point out that physical inactivity, together with a poor diet have been said to account for at least 400 thousand deaths each year in the United States. ${ }^{69}$ Should this number be close to reality, obesity-related death would be second only to tobacco use as the leading cause of preventable death in the United States. ${ }^{70}$ In the face of such

$66 \quad I d$.

67 JOHN C. LIU, AUDIT REPORT ON THE DEPARTMENT OF EDUCATION'S COMPLIANCE WITH THE PHYSICAL EDUCATION REGULATIONS IN ELEMENTARY SCHOOLS (2011), available at http://www. comptroller.nyc.gov/bureaus/audit/PDF_FILES_2011/MD11_083A.pdf.

68 Hurd, supra note 64 ("When Dr. David Satcher, the former surgeon general, gave the Martin Luther King Jr. address at Saginaw Valley State University in January, he emphasized the importance of physical education for every child. Ironically, that same month, the Buena Vista School District cut physical education classes for all students in the district, from preschool through eighth grade. Of course, schools need to focus on academics, but educators also need to focus on the whole individual - including their physical and psychological wellbeing. Physical education classes improve motor skills and hand-eye coordination, encourage cooperative learning and the team concept, reduce stress and anxiety and increase self-esteem. With the pressure of standardized testing in the classroom, students are challenged to learn more and more. This creates stress, which often erupts negatively. Physical education classes provide an outlet for children to let off pentup energy in positive ways.").

69 Katherine M. Flegal et al., Excess Deaths Associated With Underweight, Overweight, and Obesity, 293 JAMA 1861 (2005).

70 J. Michael McGinnis \& William H. Foege, Actual Causes of Death in the United States, 270 JAMA 2207 (1993). 
dire statistics and inordinate costs, not having a national program for implementing physical education in the public school system is irresponsible and reckless. Because of the gravity of the problem and to reverse the current trend, it is critical that there be uniform federal minimum standards of physical education programs that could be incorporated into public schools curriculum. To the extent a particular state chooses to exceed the federal standards, it should be free to implement its own program. However, the federal standards would pre-empt any state law that falls short of its requirements.

To understand why federal legislation is necessary, it is important to look at some of the states where standards are either completely lacking, fall short of anything reasonable, or are wholly conceptual in nature. For example the ten states with the highest childhood obesity rates as of 2008 have no physical activity requirement laws. ${ }^{71}$ These states are: Kentucky, Arkansas, Texas, Alabama, Tennessee, South Carolina, West Virginia, Missouri, Mississippi, and Michigan. ${ }^{72}$ On the other hand, some of the states with the lowest childhood obesity rates, such as Colorado and Oregon, have some of the strictest requirements for physical education. ${ }^{73}$ This is not likely a simple coincidence, even

71 F as in Fat: How Obesity Threatens America's Future 2011, TRUST FOR AMERICA'S HEALTH (July 2011), http://healthyamericans. org/report/88/; Childhood Obesity - 2008 Update and Legislative of Policy Options, NATIONAL CONFERENCE OF STATE LEGISLATURES, http://www.ncsl.org/Default.aspx?TabId=13883 (last visited Mar. 21, 2013).

$72 \mathrm{Id}$

73 Colorado's Children's wellness physical activity requirement statute declares that:

(3)(a) Each school district board of education shall adopt a physical activity policy that incorporates into the schedule of each student attending an elementary school the opportunity for the student to engage in:

(I) A minimum of six hundred minutes of physical activity per month if the classes at the school meet five days per week and the student attends school for a full day;

(II) A minimum of three hundred minutes of physical activity per month if the classes at the school 
with the existence of outliers such as Montana, where there are no strict requirements, and yet the childhood obesity rate is relatively low. Montana is in stark contrast to a state like Georgia where there are no physical education requirements and the childhood obesity rate is critically high. ${ }^{74}$

meet five days per week and the student attends school for a half day;

(III) A minimum of thirty minutes of physical activity per day if the classes at the school meet fewer than five days per week and the student attends school for a full day; and

(IV) A minimum of fifteen minutes of physical activity per day if the classes at the school meet fewer than five days per week and the student attends school for a half day.

(b) The physical activity policy may include an exception for any month that includes a planned or unplanned full-day or half-day school closure.

Colo. REV. STAT. § 22-32-136.5 (2012); Oregon's Physical education participation; minimum requirements, exceptions, professional development statute declares that:

(1)... Students in kindergarten through grade 5 shall participate in physical eduction for at least 150 minutes during each school week. Students in grades 6 through 8 shall participate in physical education for at least 225 minutes during each school week.

(2) . . . The instruction shall be a sequential, developmentally appropriate curriculum that is designed, implemented, and evaluated to help students develop the knowledge, motor skills, self-management skills, attitudes and confidence needed to adopt and maintain physical activity throughout their lives.

(3) School districts and public charter schools shall devote at least 50 percent of physical education class time to actual physical activity in each school week, with as much time as possible spent in moderate physical activity.

OR. REV. STAT. § 329.496 (2012) (effective July 1, 2017).

74 How Obesity Threatens America's Future 2011, supra note 71; 2008 Update and Overview of Policy Options, supra note 71. 
While recognizing that a federal mandate requiring minimum standards of physical education be incorporated in the nation's public schools curriculum at all grade levels is necessary and imperative to address the childhood obesity crisis, it is important to acknowledge that childhood obesity has a direct impact on states, and that each state could arguably have good reasons to design specific or unique individual programs. However, while a state by state solution may seem theoretically more appropriate, federal minimum standards will not defeat state initiatives as states should be allowed to go above and beyond federal standards.

In states that have no standards or their standards fall short of the federal minimum requirements, the federal standards will prevail. For example, in a state like Indiana where the law-with respect to childhood obesity-is almost wholly conceptual (no established state task force, no BMI screening mandate, no physical activity requirements), and the legislature has not been able to amass enough political support to advance any new legislation that could make a meaningful difference in the state's childhood obesity rate (29.9\% as of 2007 ), federal standards will prevail provided such standards can withstand potential constitutional challenges. ${ }^{75}$

\section{A FEDERAL MANDATE WILl Withstand a Constitutional Challenge}

The greatest handicap facing any federal mandate designed to incorporate minimum standards of physical education into the public school system is a constitutional challenge. It could be argued that Congress's enumerated powers described in Articles 1 through 8 of the Constitution do not expand into regulating the shapes and sizes of

75 The Henry J. Kaiser Family Foundation, Indiana: State Laws Addressing Childhood Obesity, 2011, STATEHEALTHFACTS.ORG, http://www.statehealthfacts.org/profileind.jsp?rgn $=16 \&$ ind $=52 \&$ cat $=2$ (last visited Jan. 14, 2013); Issues and Research: Childhood Overweight and Obesity Trends, NATIONAL CONFERENCE OF STATE LEGISLATURES, http://www.ncsl.org/?tabid=13877 (last visited Jan. 14, 2013). 
children of the United States. ${ }^{76}$ It could also be argued that the Tenth Amendment implicitly places such regulation within the domain of state power. ${ }^{77}$ In addition, within the context of the state police power to regulate health, safety, welfare and morals, ${ }^{78}$ it could be argued that the federal government will over-extend its power by trying to regulate an area that is traditionally governed by state laws. ${ }^{79}$

Notwithstanding, the U.S Supreme Court, in United States v. Darby, concluded that the Tenth Amendment will not stand in the way of the federal government. ${ }^{80}$ The

76 U.S. CONST. art. I, § 8:

Congress shall have Power To lay and collect Taxes, Duties, Imports and Excises, to pay the Debts and provide for the common Defence and general Welfare of the United States; . . . To borrow Money on the credit of the United States; To regulate Commerce . . .; To establish a uniform Rule of Naturalization, and . . . Bankruptcies ...; To coin Money .. .; To establish Post Offices . . .; To promote the Progress of Science and useful Arts . . .; To constitute Tribunals inferior to the supreme Court; To define and punish Piracies and Felonies committed on the high Seas ...; To declare War ....; To raise and support Armies ...; To provide and maintain a Navy.

77 U.S. CONST. amend. X (specifying that "[t]he powers not delegated to the United States by the Constitution, nor prohibited by it to the States, are reserved to the States respectively, or to the people").

78 Jorge E. Galva et al., Public Health Strategy and the Police Powers of the State, 120 PUB. HEALTH REP. 20 (2005), available at http://www.ncbi.nlm.nih.gov/pmc/articles/PMC2569983/ (last visited Jan. 14, 2013).

79 Solid Waste v. U.S Army Corps of Engineers, 531 U.S. 159 (2001) (striking down a federal land use regulation by concluding that local land use regulation is expressly reserved to the states by the Tenth Amendment).

80 United States v. Darby, 312 U.S. 100, 124 (1941) (holding that "the 10th Amendment states but a truism that all is retained which has not been surrendered"). The Court in Darby further said that "there is nothing in the history of its adoption to suggest that it was more than declaratory of the relationship between the national and state governments as it had been established by the Constitution before the amendment or that its purpose was other than to allay fears that the 
Supreme Court rarely declares laws unconstitutional for violating the Tenth Amendment. ${ }^{81}$ For example, in $N e w$ York v. United States, the Court ruled that the Tenth Amendment is violated in cases where the federal government compels the states to enforce federal statutes. ${ }^{82}$ Notwithstanding, despite finding that the federal government had overreached in its powers, Justice O'Connor, writing for the majority, explicitly stated that the federal government can impose on the states certain regulations through the spending power (e.g. by attaching conditions to the receipt of federal funds). ${ }^{83}$ Such probative federal jurisprudential precedents make it more difficult to argue that federal minimum standards for physical education will not withstand a constitutional challenge.

Furthermore, the school setting is one of the most appropriate places to apply the model announced in $N e w$ York v. United States (and also South Dakota v. Dole) because the federal government currently provides substantial funding to the states for school related

new national government might seek to exercise powers not granted, and that the states might not be able to exercise fully their reserved powers."

81 See generally New York v. United States, 505 U.S. 144, 149 (1992) (recognizing for only the second time within a fifty-five year span that the Court invalidated a portion of a federal law for violating the Tenth Amendment).

82 See generally id. (illustrating when the Supreme Court would invalidate a federal law for violating the Tenth Amendment). New York v. United States involved a challenge to a portion of the Low-Level Radioactive Waste Policy Amendments Act of 1985. The Act stipulated three incentives for states to comply with congressional statutory obligations to accommodate the disposal of low-level radioactive waste. The first two incentives were pecuniary. The third, which brought about the constitutional challenge, obligated states to take title to any waste within their borders that was not disposed of prior to January 1, 1996, and made each state liable for all damages directly related to the waste. The Court ruled that the imposition of that obligation on the states violated the Tenth Amendment. Justice Sandra Day O'Connor indicted that the federal government can encourage the states to adopt certain regulations through the spending power (e.g. by attaching conditions to the receipt of federal funds). See also South Dakota v. Dole, 483 U.S. 203 (1987).

83 Dole, 483 U.S at 206 (concluding that Congress may attach reasonable conditions to funds disbursed to the states). 
expenditures. ${ }^{84}$ States have often consented to federal requirements in order to access federal grants and other resources. ${ }^{85}$ For example, states cannot receive federal highway funding unless they implement federally-approved speed limits and drinking ages. ${ }^{86}$ Universities cannot receive federal research funding if they do not provide gender parity in athletic offerings. ${ }^{87}$ Historically, states must offer a prescribed curriculum (including science) in order to receive federal grants for higher education. ${ }^{88}$ Also, in the mid-1960s federal grants were used to influence southern school boards to adopt extremely unpopular conditions-desegregating students and teachers in public schools. ${ }^{89}$

More recently, according to Elizabeth Cascio (cited above), the threat of withdrawal of federal education funds "has been used to encourage states and districts to comply with the accountability requirements under the No Child Left Behind Act."90 It is well established that the federal government can use its constitutional spending power to affect state and local policies. ${ }^{91} \mathrm{~A}$ federal mandate requiring minimum standards of physical education in grade schools-under the threat of withholding federal funds-is no different than any of the above mentioned laws that have

84 Summary of Discretionary Funds, FY 2009 Request, U.S. DEPT. OF EDUC. (Jan. 31, 2008), http://www2.ed.gov/about/overview/budget/ budget09/summary/appendix1.pdf (last visited Jan. 14, 2013).

85 Robert JAY DILGER, CONG. RESEARCH SERV., R 40431, FEDERAlism Issues IN SURface TRANsPortation POLICY: PAST AND PRESENT (2011), available at http://assets.opencrs.com/rpts/R40431 20110420.pdf.

86 Dole, 483 U.S. at 205.

87 See generally Favia v. Indiana University of Pennsylvania, 7 F.3d 332 (3rd Cir. 1993).

88 See generally Elizabeth Cascio et al., Paying for Progress: Conditional Grants and the Desegregation of Southern Schools, 125 Q.J.ECON. 445 (2010), available at http://11.ccpr.ucla.edu/papers/QJEP4P.pdf.

89 Id.

$90 \quad I d$. at 445 .

91 Dole, 483 U.S. at 204 (ruling that Congress could use its taxing and spending clauses to pressure states to comply with national drinking-age standards). 
been found to be constitutional. Therefore, such a mandate is likely to be ruled constitutional as well.

For those who think the federal government cannot be the solution, it should not be forgotten that regulations that are now taken completely for granted sparked fierce controversy in their time (Clean Air Act, Clean Water Act). ${ }^{92}$ Many often characterized legislation such as the Clean Air Act and the Clean Water Act as being paternalistic and as power grabs by the government. ${ }^{93} \mathrm{Few}$, today, will argue the nation has not benefited from these legislations.

In a more recent example, the first reports recommending that government be involved in regulating the tobacco industry were controversial. ${ }^{94}$ Some, defending smokers' rights, denounced a tobacco tax and potential advertising bans as an assault on liberty, and as health education propaganda..$^{95}$ While the debate might not be fully settled today, benefits that continue to flow from regulating the tobacco industry are quite measurable. ${ }^{96}$ It is critical to

92 Edmund S. Muskie, The Clean Air Act: A Commitment to Public Health http://www.cleanairtrust.org/nepa2cercla.html (last visited Mar. 9, 2013); see also Levin Statement in Opposition to the Clean Water Cooperative Federalism Act, http://levin.house.gov/levin-statementopposition-clean-water-cooperative-federalism-act (last visited Mar. 9, 2013).

$93 \quad I d$.

94 Joanna E Cohen et. Al, Political Ideology and Tobacco Control http://tobaccocontrol.bmj.com/content/9/3/263.full (last visited Mar. 9, 2013).

95 Id.

96 Lorenzo Richiardi et al., Cardiovascular Benefits of Smoking Regulations: The Effect of Decreased Exposure to Passive Smoking, 48 PREVENTIVE MED. 167 (2009), available at http://www.sciencedirect.com/ science/article/pii/S0091743508006294:

Studies conducted in the USA and Europe have shown a reduction in the number of hospital admissions for acute myocardial infarction (AMI) in the months following the introduction of regulations banning smoking in public places. ([Sargent et al., 2004], [Barone-Adesi et al., 2006], [Bartecchi et al., 2006], [Cronin et al., 2007], [Juster et al., 2007], [Khuder et al., 2007], [Seo and Torabi, 2007], [Cesaroni et al., 2008], [Lemstra et al., 2008], [Pell et al., 2008]). . . The decreases observed 
understand that these regulations govern broad social issues with national effects that can be better categorized as infrastructure issues that are outside the scope of one individual, but from which each can benefit. Their goals (regulations) are to promote the nation's general welfareCongress' primary duty under the Constitution. ${ }^{97}$ Critics may respond to government intervention in relation to individual lifestyle and behavioral choices with rousing cries for personal liberty, and claim that such micromanagement of the individual is a manifestation of authoritarianism. ${ }^{98}$ However, dismissing government intervention as authoritarianism, or the emergence of absolutism limits debate about the possible benefits of such intervention. ${ }^{99}$ Any government that wants to change the behavior of companies or the public in response to a perceived or actual health risk (such as the one presented by the childhood obesity crisis) must be willing to take bold steps for the greater good. A federal program mandating minimum standards of physical education in the nation's public schools is a bold step for the greater good and the nation's general welfare.

It could debatably be said that almost every government intervention in the public arena, at one time or another, have been criticized as a sign of tyranny, "nanny-statism", or the end of individual freedom. Yet the subsequent evidence often unmasks the appreciable individual and public health benefits of once-highly opposed interventions. ${ }^{100}$ These results arguably mitigate the

ranged from a $40 \%$ decrease found in Helena, Montana, USA (Sargent et al., 2004) to an 8\% reduction seen in the State of New York. (Juster et al., 2007). Smoking regulations decrease exposure to passive smoking and may indirectly decrease active smoking.

97 U.S. ConsT. art. I, $\S 8$. ("Congress shall . . . provide for the common Defense and general Welfare of the United States.").

98 Id.

99 J. Hoek, Public Health, Regulation and the Nanny State Fallacy, http://ro.uow.edu.au/cgi/viewcontent.cgi?article=1001\&context= insm08 (last visited Mar. 9, 2013).

100 EPA, Benefit and Costs of the Clean Air Act, http://www.epa. gov/air/sect812/economy.html (last visited Mar. 9, 2013). 
negative effects from limitations on individual freedom and choice. As opposed to blanket criticism of unwarranted government interference, one must look at such government necessitated intervention as "stewardship" to understand the justification and impact. Stewardship implies that government has a responsibility for protecting national health, and to serving in the public interest and for the public good. ${ }^{101}$ While the concept of free market, state rights and freedom of choice are noble and must be defended, anchoring critical choices for the nation's well-being to a distinct political ideology advances neither free market, nor state rights, or freedom. The solution to the childhood obesity crisis should not be required to first worship at the foothill of political dogma.

Some political theorists take the position that such government intervention is not in conflict with individual freedom. Sunstein and Thaler, for example, propound that public policy helps to eliminate obviously bad choices and encourages more positive ones to promote individual and general well-being. ${ }^{102}$ Certainly, most would like to see childhood obesity become a thing of the past. If government intervention can make it easier to accomplish such an important goal, then it is quite intransigent to argue that requiring physical education in public schools is an affront on individual liberty.

Overweight children and obesity-related expenses affect everyone. The social stigma and the increased health care expenses associated with childhood obesity necessitate and reflect the urgency of a comprehensive undertaking of the national government. Given that up to $80 \%$ of the nation's children attend public schools, a government intervention through the public school system would effectively reach the

101 See generally Richard B. Saltman \& Odile Ferroussier-Davis, The Concept of Stewardship in Health Policy, 78 BULL. WORLD HEALTH ORG. 732 (2000), available at http://www.scielosp.org/pdf/bwho/v78n6/ v78n6a05.pdf.

102 See generally Cass R. Sunstein \& Richard H. Thaler, Libertarian Paternalism is not an Oxymoron, 70 U. CHI.L. REv. 1159 (2003). 
targeted audience. ${ }^{103} \mathrm{~A}$ recent position statement issued by the American Heart Association supports this assertion, concluding that "schools could become the central element in a system that ensures that students participate in enough physical activity to develop healthy lifestyles."104 Currently, most states require some form of physical education in schools-though many are conceptual and with great disparity. ${ }^{105}$ To address both the conceptual and the disparity problems, a comprehensive federal mandate, with specific standards, requiring the incorporation of physical education into the nation's public school curriculum is the solution.

Given the challenges that the United States faces as a nation, it must come together to defeat this crisis. While some might question the constitutional power of the government to require minimum standards of physical activity at all grade levels in all public schools, these types of questions, as indicated above, permeated the regulation of the Tobacco Industry during the 1980s and 90s. As it has become less and less debatable that the childhood obesity crisis is a national problem, it should be addressed at the national level, and the role of the federal government should be recognized and accepted. ${ }^{106}$ Besides, the judicial

103 Inst. of Educ. and Science, Fast Facts, NATIONAL CENTER FOR EDUCATION STATISTICS, http://nces.ed.gov/fastfacts/display.asp?id=6 (last visited Jan. 14, 2013).

104 Russell R. Pate, et al., Promoting Physical Activity in Children and Youth, 114 CIRCULATION: AM. HEART AssOC. 1214 (2006), available at http://circ.ahajournals.org/content/114/11/1214.full (arguing that "[i]t appears the time has come to consider a markedly expanded role for schools in providing physical activity to our children and youth. Schools could become the central element in a . . system that ensures that students participate in enough physical activity to develop healthy lifestyles").

105 F as in Fat: How Obesity Threatens America's Future 2010, TRUST FOR AMERICA'S HEALTH (June 2010), http://healthyamericans. org/reports/obesity2010/ (stating that "[e]very state has some form of physical education requirement for schools, but these requirements are often limited, not enforced or do not meet adequate quality standards").

106 President Barack Obama, Presidential Proclamation--National Childhood Obesity Awareness Month, WHITEHousE.GOV (September 01, 2010), http://www.whitehouse.gov/the-press-office/2010/09/01/ presidential- 
precedents make it likely that federally mandated minimum standards enforced through the government spending power will likely sustain any potential constitutional challenge. ${ }^{107}$

\section{SOLUTIONS to THE PROBLEMS OF CHILDHOOD OBESITY}

\section{A. Principal}

In August 1994, the American Heart Association's Children's Heart Health Conference met to identify strategies for promoting healthier children. At the end of the conference, the organization's "recommendations regarding children's physical activity were developed to conform to the goals of Healthy People 2000 as well as the recommendations from the American Heart Association Task Force on Physical Activity."108 Its guidelines for physical education programs are outlined below and are built upon to provide a more comprehensive approach to resolving this crisis:

proclamation-national-childhood-obesity-awareness-month (last visited Jan. 14, 2013). President Barack Obama established that September is National Childhood Obesity Awareness Month, proclaiming that:

One of the greatest responsibilities we have as a Nation is to safeguard the health and well-being of our children. We now face a national childhood obesity crisis, with nearly one in every three of America's children being overweight or obese. There are concrete steps we can take right away as concerned parents, caregivers, educators, loved ones, and a Nation to ensure that our children are able to live full and active lives. During National Childhood Obesity Awareness Month, I urge all Americans to take action to meet our national goal of solving the problem of childhood obesity within a generation.

107 South Dakota v. Dole, 483 U.S. 203, 206-07 (1987); see also New York v. United States, 505 U.S. 144, 171-73 (1992).

108 Samuel S. Gidding et al., Improving Children's Heart Health: $A$ Report from the American Heart Association's Children's Heart Health Conference, 65 J. SCH. HEALTH 129 (1995), available at http:// onlinelibrary.wiley.com/doi/10.1111/j.1746-1561.1995.tb06215.x/abstract. 
a. "Provide enjoyable experiences that enhance students' confidence in their ability to engage in physical activity."109

This can be expanded upon by developing a national strategic plan to increase physical activity. Such can be accomplished (in part) by earmarking transportation funding to increase physical activity (e.g., bike and walking paths, buses with bike racks, traffic calming), and by designing activity-friendly communities.

b. "Provide a significant percentage of students' recommended weekly amount of physical activity." 110

Current laws in states like Colorado and Oregon-where the legislatures unequivocally mandate the amount of physical activities that students must be exposed to as part of the overall curriculum-is a "starting point" for a federal mandate.111 "Starting point" is emphasized because federal standards do not have to mirror these laws; rather they could be adjusted, or be built upon for a more complete approach.

c. "Develop participation competence in developmentally appropriate physical activities."112

This is to say that physical activity is not a one size fits all; therefore, activities need to be tailored to a child's appropriate age and condition(s).

d. "Impart knowledge about the health benefits of physical activity."113

This can be done by supporting programs that teach both parents and children about the benefit of physical activity. Such programs can be funded through conditional federal grants.

e. "Promote mastery of behavioral skills needed for maintenance of an active lifestyle."114

109 Id.

$110 \mathrm{Id}$.

111 Colo. Rev. Stat. $\S 22-32-136.5$ (2012); OR. REv. STAT. $\S$ 329.496-2 (2012).

112 Gidding, supra note 108, at 129.

113 Id.

114 Id. 
It is important to recognize that winning the fight against childhood obesity should not be seasonal or cyclical. Children need to be taught that maintaining an active lifestyle does not end beyond the school walls, and that it should be part of everything they do.

f. "Promote students' participation in physical activity in school, community, and home settings."115

These can be done by promoting walking and biking to school; enhancing physical education; offering incentives for physical activity, striving to decrease sedentary behaviors; and encouraging celebrities to help promote physical activity and healthy eating. ${ }^{116}$

Taken together, these are all activities that can and should be implemented through a federally mandated program. Based on the Supreme Court precedents, it is well within the federal government authority to establish such a mandate using the spending power. ${ }^{117}$

\section{B. Alternative Solution}

The federal government could simply provide the necessary funding while allowing states to fashion programs and choose how these programs are implemented. Such an approach would seek to strengthen existing requirements that are working-such as those in Oregon and Colorado, to incentivize states with no requirements whatsoever to take the first step, and to hasten potential initiatives that may

115 Id.

116 Marion Nestle, Food Marketing and Childhood Obesity - A Matter of Policy, NEW ENGL. J. MED. 2527 (2006), available at http://www.nejm.org/doi/full/10.1056/NEJMp068014. Nestle discusses whether food marketing is responsible: "[t]he [Institute of Medicine ("IOM")] analyzes the results of 123 published, peer-reviewed studies addressing links between food marketing and children's preferences, requests, consumption, and adiposity. Despite Talmudic parsing of the limitations of the research, the IOM finds that the preponderance of the evidence supports the links" that food marketing is a contributing factor as it promotes unhealthy eating. Unhealthy eating is, at least minimally, a contributing factor to the childhood obesity crisis.

117 See generally South Dakota v. Dole, 483 U.S. 203 (1987); New York v. United States, 505 U.S. 144, 167-68 (1992). 
be hobbling along due to financial strain. ${ }^{118}$ However, given the experiences of the past decades, which unequivocally highlight the states' failures in addressing the childhood obesity crisis, there ought to be tremendous reservation to letting the states once again take almost complete charge of any attempt at a solution to the childhood obesity crisis. ${ }^{119}$

\section{CONCLUSION}

Childhood obesity is a national problem that has so far contributed tremendously to the amount of money the nation spends on health care. This crisis demands a national solution. While it is in the interest of our system of federalism to respect and preserve states' power to police health, safety, morals and welfare of their own citizens, it is important to understand that a changing environment has caused the childhood obesity epidemic, and that the environment, as it is today, is an appropriate place for federal intervention.

Addressing this problem has been difficult (as evidenced by the historical records of obesity in general and childhood obesity in particular) and remains costly; thus prevention must be a national priority. Justice Silberman (of the District of Columbia Circuit), in upholding the Affordable Care Act in 2011, reminded us that almost half a century ago, the Supreme Court declared in Heart of Atlanta Motel v. United States that "the right to be free from federal

118 See generally COLO. REV. STAT. § 22-32-136.5 (2012); OR. REV. STAT. § 329.496 (2012).

119 Public Health Law: Winnable Battles, Physical Activity for School Age Children, CENTERs FOR DISEASE CONTROL AND PREvention, http://www.cdc.gov/phlp/winnable/school_activity.html (last visited Jan. 14, 2013). According to the CDC, "federal law does not prescribe minimum standards for physical education in schools; instead, the federal government relies on grant programs administered by the Departments of Education and Transportation to create incentives that promote [(not mandate)] physical activity in the school setting."

Those incentives have not been successful in pushing states to adopt meaningful physical education laws as evidenced by many states that either have adopted a conceptual framework of physical education without actual requirement. 
regulation is not absolute, and yields to the imperative that Congress be free to forge national solutions to national problems, no matter how local-or seemingly passive-their individual origins." 120 Given the documented failures of the states to resolve this issue of childhood obesity, ${ }^{121}$ a federal mandate requiring all public schools to incorporate specific standards of physical education in their curriculum is necessary to bring about uniform compliance that would ensure a comprehensive approach to this exigency.

120 See Susan Seven-Sky v. Eric Holder, No. 1:10-cv-00950 (2011); see Heart of Atlanta Motel, Inc. v. United States, 379 U.S. 241, 258-59 (1964).

121 How Obesity Threatens America's Future 2010, supra note 105. 